\title{
Hyperhomocysteinemia is a Biomarker of Sulfur-Deficiency in Human Morbidities
}

\author{
Yves Ingenbleek*
}

Laboratory of Nutrition, University Louis Pasteur Strasbourg, France

\begin{abstract}
Methionine (Met) is crucially involved in the synthesis of S-compounds endowed with molecular, structural and functional properties of survival value. Dietary Met may undergo transmethylation processes to release homocysteine (Hcy) which may either be regenerated to Met following remethylation (RM) pathways or catabolized along the transsulfuration (TS) cascade. The activity of enzymes governing RM and TS pathways is depending on pyridoxine, folate and cobalamin bioavailability. Dietary restriction in any of these watersoluble B-vitamins may lead to hyperhomocysteinemia (HHcy) causing a panoply of cardiovascular disorders. Taken together, the vitamin triad only affords partial account of Hcy variance, prompting the search for additional causal factor(s). Body composition studies demonstrate that nitrogen (N) and sulfur (S) maintain tightly correlated concentrations in tissues of both healthy subjects and diseased patients. Any morbid condition characterized by insufficient $\mathrm{N}$ intake or assimilation, as seen in protein malnutrition or intestinal malabsorption, reduces body $\mathrm{S}$ accretion rates. Excessive urinary $\mathrm{N}$-losses, as reported in acute or chronic inflammatory disorders, entail proportionate obligatory S-losses. As a result, lean body mass (LBM) undergoes downsizing and concomitant depletion of $\mathrm{N}$ and $\mathrm{S}$ body stores which depresses the activity of cystathionine- $\beta$-synthase, thereby promoting upstream accumulation of Hcy and overstimulation of RM processes. HHcy thus appears as the dark side of efforts developed by S-deprived patients to safeguard Met homeostasis. Irrespective of vitamin-B status, Hcy values are negatively correlated with LBM shrinkage well identified by the serial measurement of plasma transthyretin (TTR). The Sdeprivation theory fulfills the gap and allows full causal coverage of the metabolic anomaly, hence providing together with vitamin-deficiencies an unifying overview of the main nutritional determinants implicated in HHcy epidemiology.
\end{abstract}

Keywords: Body composition, nutritional status, sulfur-deficiency, hyperhomocysteinemia, cardiovascular diseases, transthyretin.

\section{INTRODUCTION}

Sulfur (S) bears the number 16 in the periodic table of elements. There is geological evidence that $\mathrm{S}$ was present early among primordial compounds, either in free form or combined with other elements. In the earth's crust, $\mathrm{S}$ naturally occurs as a mixture of 4 isotopes, the most abundant being ${ }^{32} \mathrm{~S}(95.1 \%)$. The biological cycle of $\mathrm{S}$ is thought to have been initiated by microorganisms transforming inorganic sulfate groups into gazeous hydrogen sulfide, a form of primitive respiration at the origin of anaerobic life on earth [1]. The later occurrence of photosynthesis in microscopic plants has created reciprocal exchanges between anaerobic and aerobic ecosystems [2]. The progressive enrichment in oxygen of the atmosphere has favored the emergence of higher plants and aerobic animals [3]. S metabolism is highly regulated in the plant kingdom and its bioavailability is regarded as a limiting factor for protein synthesis and vegetable growth [4].

In higher Vertebrate tissues, $\mathrm{S}$ is the seventh most abundant element after $\mathrm{H}, \mathrm{C}, \mathrm{O}, \mathrm{N}, \mathrm{Ca}$ and $\mathrm{P}$. Total body sulfur (TBS) of a reference healthy adult man weighing $70 \mathrm{~kg}$ amounts to $140 \mathrm{~g}(4,400 \mathrm{mmol})$ meaning the same level of

*Address correspondence to this author at the University Louis Pasteur Strasbourg, Faculty of Pharmacy, Laboratory of Nutrition, 74, Route du Rhin, 67400 Illkirch, France; Tel: 00-33-467 7487 17;

E-mail: ingen@pharma.u-strasbg.fr magnitude than that of total body potassium (TBK, 3,600 mmol) [5]. While there exists an extensive scientific literature describing the toxicological properties of $\mathrm{S}$ and $\mathrm{S}$ derivatives on living organisms [6], surprisingly enough, no report of S-deprivation is available in human nutrition up to now. This lacuna is all the more intriguing as the lack of most other elements such as magnesium, iron, zinc, and even of trace-elements such as fluorine, iodine or selenium whose concentration is meaningfully lower [5] are all held responsible for well-defined bodily disorders [7]. We have hereunder collected data describing the conditions and mechanisms whereby S-deficiency may occur in diseased persons. Although this physiopathological condition is unrecognized up to now, we assume that it is one of the commonest disorders harming mankind. Hyperhomocysteinemia appears to be the hallmark of S-deficiency and the result of disease-induced alterations in body composition.

\section{BODY COMPOSITION STUDIES}

The human body may be divided into 2 major compartments, namely fat mass (FM) and fat free mass (FFM) that are obtained by substracting FM from body weight (BW). The fat cell mass sequesters about $80 \%$ of the total body lipids, is poorly hydrated and contains only small amounts of lean tissues and nonfat constituents. FFM comprises the sizeable part of lean tissues and minor mineral compounds, the latter totaling about $1.7 \mathrm{~kg}$ or $2.5 \%$ of $\mathrm{BW}$ in the refer- 
ence man [5]. Substraction of mineral mass from FFM provides lean body mass (LBM), a composite agglomeration of organs and tissues which represent about two thirds of BW in healthy individuals. LBM accounts for most of total body proteins (TBP) and of total body nitrogen (TBN) assuming a mean 6.25 ratio between protein and $\mathrm{N}$ content [8]. Schematically, LBM aggregates 3 components : A metabolically inert and non-exchangeable $\mathrm{N}$ component (cytoskeleton; tendons; cartilages; non-soluble collagen compounds) representing about $54 \%$ of body cell mass at the timing of death from long-lasting wasting disorders [9] and exchangeable tissues which may be in turn subdivided into a relatively small visceral pool comprising rapidly turning over tissues (liver; intestinal mucosa; thymoleukocytic cell lines) and a large structural pool (skeletal muscle, SM; skin; soluble collagen compounds) made up of tissues characterized by slow metabolic activities [10]. However, because the fractional synthesis and renewal rates of the liver and gut mucosa are about 10- to 20- times more rapid than that of SM mass, it can be inferred that the small-sized visceral pool makes an absolute contribution to the daily turnover of body proteins at least equal to that defining the structural pool [11]. SM is by far the main ponderal representative of the structural compartment [12] having peculiar importance in nutritional studies due to its capacity to serve as major reservoir of amino acids (AAs) and dispenser of gluconeogenic substrates. The alterations affecting SM mass in the course of disease process are evaluated by the measurement of creatinine [13]. This last end-product represents less than $10 \%$ of all $\mathrm{N}$-catabolites recovered in the urinary output, being nevertheless regarded as a useful predictor of disease outcome [14]. Urea usually represents up to $90 \%$ of all urinary Ncatabolites and validly reflects the level of deamination / transamination reactions occurring in all body tissues, prevailing particularly in organs endowed with high metabolic turnover. Confrontation of creatinine and urea values may therefore provide a balanced appraisal of the activities developed in both structural and visceral pools.

Table 1 collects findings from several research groups $[12,15-17]$ showing the main protein components of the body in healthy men and women. Whatever the analytical methodology utilized, all selected parameters demonstrate a clear-cut gender dimorphism (whether referring to absolute values or body weight or body height ratios) remaining stabilized in the form of plateau levels throughout full sexual maturity. Children undergo continuing growth from birth until the onset of adolescence without significant differences in body composition during the prepubertal period [18-20]. The advent of adolescence, characterized by sexual differences with development of enlarged LBM and SM sizes in teenage boys and increased FM in girls, is attributed to sex hormones and differentiated responsiveness to growth factors and anabolic stimuli [21,22]. During adulthood, all protein components of human body gathered in Table 1 remain unaltered until the end of the fifth decade, manifesting thereafter an age-dependent curvilinear decline with an accelerated decrease after 65 years [16,23]. In particular, SM undergoes 15 $\%$ reduction in size per decade [12] with a trend toward sarcopenia more marked in elderly men [24,25]. These involutive processes are well-identified by the measurement of plasma transthyretin (TTR) using recently published results [10] obtained on nearly 70,000 healthy US citizens by scientists belonging to the Foundation for Blood Research (Scarborough, Maine 04074). The evolutionary TTR patterns point to striking similarities with body protein components shown in Table 1. TTR plasma levels are indeed minimal at birth, disclose linear and superimposable increase in (pre)school children, then revealing hormonally-induced dimorphic partitioning with higher values recorded in adolescent boys [10]. These gender peculiarities are maintained unmodified in both sexes until the end of adulthood thereafter disclosing progressive lowering with a steeper slope affecting old-age males [10]. We therefore assume that TTR is in all classes of age a useful indicator of overall protein nutritional status, and more specifically of LBM status [10].

\section{THE METHIONINE - HOMOCYSTEINE CYCLE IN HUMAN BEINGS}

The principal source of $\mathrm{S}$ fulfilling body requirements is provided by dietary methionine (Met). Among the 8 indispensable AAs (IAAs), Met is the only S-containing molecule which may undergo activation to $\mathrm{S}$-adenosylmethionine (SAM) and serve as donor of $\mathrm{CH}_{3}$ groups stimulating the production of creatine and other acceptor molecules through transmethylation (TM) processes [26]. After splanchnic uptake, dietary Met may also be incorporated as such into the AA sequence of body proteins or converted to homocysteine (Hcy), an intermediary metabolite situated at a crucial crossroad regulating the fate of S-containing compounds. Hcy may either undergo remethylation $(\mathrm{RM})$ process to regenerate Met under the control of Met-synthase (EC 2.1.1.13) or irreversibly committed into the transsulfuration (TS) cascade - initiated by the rate-limiting and multifunctional cystathionine- $\beta$-synthase ( $\mathrm{C} \beta \mathrm{S}, \mathrm{EC}$ 4.2.1.22) enzyme - yielding $\mathrm{SO}_{4}{ }^{2-}$ oxyanions as end-product (Fig. 1). Three dietary watersoluble B-vitamins are implicated in the regulation of the Hcy-Met cycle. Folates (vit $\mathrm{B}_{9}$ ) is regarded as the most powerful agent, working as supplier of $\mathrm{CH}_{3}$ groups required for $\mathrm{RM}$ processes whereas cobalamins (vit $\mathrm{B}_{12}$ ) and pyridoxal-

Table 1. Body Composition Studies Showing the Main Protein Components in Healthy Adult Humans

\begin{tabular}{|c|c|c|c|c|c|}
\hline & $\mathbf{B W}^{\mathrm{a}, \mathrm{b}}(\mathbf{k g})$ & $\mathbf{T B N}^{\mathrm{b}, \mathbf{c}}(\mathbf{k g})$ & $\mathbf{T B P}^{\mathbf{d}}(\mathbf{k g})$ & $\mathbf{S M}^{\mathbf{e}}(\mathbf{k g})$ & $\mathbf{L B M}^{\mathbf{a}, \mathbf{c}}(\mathbf{k g})$ \\
\hline \hline Males & $76-79$ & $1.8-1.9$ & $11.2-11.8$ & 33 & $54-62$ \\
\hline Females & 60 & $1.2-1.4$ & $7.5-8.7$ & 21 & $36-39$ \\
\hline
\end{tabular}

${ }^{\mathrm{a}}$ Body weight (BW) and lean body mass (LBM) measured by Battezzatti et al. [17] using bioelectric impedance analysis (BIA) and dual X-ray absorptiometry (DEXA) technologies. ${ }^{\mathrm{b}} \mathrm{BW}$ and TBN measured by Ellis et al. [16] using prompt $\gamma$-neutron activation.

${ }^{\mathrm{c}}$ TBN and LBM measured by Cohn et al. [15] using prompt $\gamma$-neutron activation.

${ }^{\mathrm{d}}$ Total body protein (TBP) is the result of TBN multiplied by 6.25 [8].

${ }^{\mathrm{e}}$ Skeletal muscle (SM) mass measured by Janssen et al. [12] using magnetic resonance imaging (MRI). 


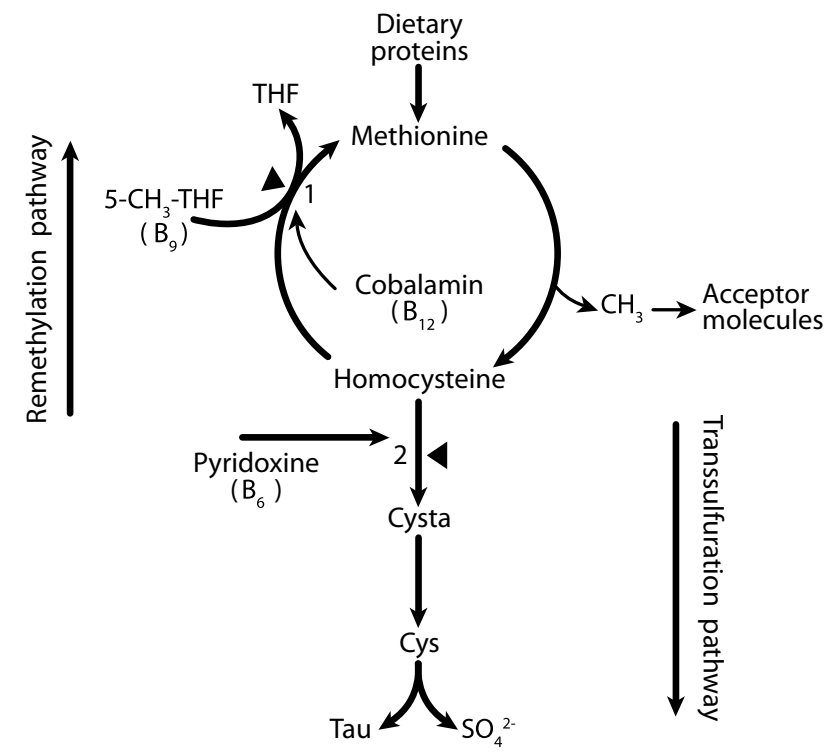

Fig. (1). Schematic configuration of the Met-Hcy cycle in higher Vertebrates. Met supplied by dietary proteins may be subjected to transmethylation (TM) process releasing $\mathrm{Hcy}$ and $\mathrm{CH}_{3}$. The latter compound is taken up by acceptor molecules (creatine, hormones, neurotransmitters, phospholipids) whereas the former may undergo either remethylation (RM) process or irreversible degradation along the transsulfuration (TS) cascade. Both RM and TS pathways stand in competition under the control of 3 watersoluble vitamins so as to maintain Met homeostasis. 5-Methyl-tetrahydrofolate $\left(5-\mathrm{CH}_{3}-\mathrm{THF}\right.$, Vit $\mathrm{B}_{9}$ ) is the donor of the $\mathrm{CH}_{3}$ group required for $\mathrm{RM}$ processes whereas cobalamins $\left(\mathrm{Vit}_{12}\right.$ ) and pyridoxine (Vit $\mathrm{B}_{6}$ ) operate as co-factors of Met-synthase $(\mathbf{1})$ and of cystathionine- $\beta$-synthase (2 ), respectively. Some Hcy-derivatives belonging to the TS pathway : cystathionine (Cysta), cysteine (Cys), taurine (Tau), and sulfaturia $\left(\mathrm{SO}_{4}{ }^{2-}\right)$ as end-product.

5'-phosphate (PLP, vit $\mathrm{B}_{6}$ ) operate as co-factors of Metsynthase and CBS, respectively. Dietary deficiency in any of the 3 vitamins may cause mild or moderate elevation in Hcy plasma values. Etiopathogenic studies have highlighted that dietary shortage in folates [27] or cobalamins [28] are both capable of depressing the activity of Met-synthase, favoring the downstream sequestration of Hcy in extracellular fluids. Dietary PLP deprivation may impair C $\beta S$ activity [29], thereby promoting the upstream accumulation of Hcy. Hyperhomocysteinemia (HHcy) is an acquired metabolic disorder recognized of increasing importance for health in the general population and working as an independent and graded risk factor for thrombovascular lesions unrelated to hypercholesterolemia, arterial hypertension, diabetes and smoking [30,31]. It is beyond the scope of this paper to review in depth the mechanisms involved in the development of these atherothrombogenic events as recent position papers have dealt with these aspects [32,33].

There exists disagreement concerning the relative role played by watersoluble vitamin-deficiencies on HHcy epidemiology. A recent review reports that their dietary deprivation causally accounts for about two thirds of all cases
[34]. We assume that this figure does not stand up to close scrutiny. Should that $2 / 3$ proportion be valid would imply that at least one third of all supranormal Hcy values are not liable for a vitamin causal explanation. The discrepancy between regression analyses and biochemical data are of peculiar relevance in the case of cobalamin status. While vitamin $\mathrm{B}_{12}$-shortage is convincingly demonstrated as one of the most prevalent nutritional deficiencies worldwide [35], its true impact on Hcy variance is surprisingly low, particularly in populations from rural developing countries whose customary diet principally consists of vegetable products. Our clinical experience mainly confined to African countries (Chad, Guinea, Ivory Coast, Senegal) indicates that the vitamin triad deficiency, taken together, yields Hcy variance data usually ranging from 20 to $30 \%$, consistent with comparable epidemiological surveys undertaken in Taiwan [36] and India [37]. Such relatively weak vitamin-related Hcy variance is best explained by the fact that the protein-energy malnutrition (PEM) component of HHcy [38] is overlooked by most investigators. Moreover, the quoted review [34] underestimates the growing body of studies showing supranormal Hcy values in spite of normal watersoluble vitamin plasma levels $[38,39]$ or those displaying high HHcy refractoriness to strong vitamin supplementation [40]. Four decades of research on the link between HHcy and cardiovascular risks have led to a deadlock in view of the increasing number of negative studies on the role of Hcy-lowering Bvitamin therapy [40,41]. Obviously, the data already available prompted the search for additional causal factors filling the gap between firmly established vitamin-deficiencies and the broader spectrum of epidemiological findings.

\section{ROLES PLAYED BY MET AND SULFUR IN HUMAN NUTRITION}

The Met molecule was discovered by Mueller [42] and its essentiality in animals was demonstrated by growth retardation of rats experiencing Met-free diets [43]. Clinical investigations undertaken in healthy adult volunteers $[44,45]$ have concluded that dietary Met given as sole S-containing AA (SAA) was sufficient to meet most, if not all, S-tissue requirements of healthy individuals of both sexes and in all age groups [45]. The neonatal period constitutes a notable exception owing to the fact that newborn children are lacking the liver cystathioninase enzyme that is required for the TS production of cysteine (Cys) and taurine (Tau) from Met [46]. It is also worth mentioning that elderly persons likely adjust less well to a reduced intake of dietary Met than do young adults [47], standing therefore more at risk of developing a protein inadequacy. The long-lasting debate that had once contemplated Cys as a surrogate supplier of $\mathrm{S}$ and as a sparing factor of Met disposal is no longer sustainable unless very low Met consumption is imposed [45]. Drinking waters from natural springs contain varying concentrations in $\mathrm{SO}_{4}{ }^{2-}$ values and constitute by far the main $S$ dietary variable in human nutrition [48]. This water supply is however of no help to improve the bioavailability of $S$ as the human body lacks the capacity to organize $\mathrm{SO}_{4}{ }^{2-}$ oxyanions. The bulk of TBS participates in protein synthetic processes in close relationship with $\mathrm{N}$, partaking similarly into 3 distinct body pools superimposed to those above-described for TBN and manifesting the same exchangeable characteristics [48]. It must nevertheless be kept in mind that all S-containing molecules do not undergo strict alignment on protein synthe- 
sis and that minute amounts of TBS may be substracted and embodied into carbohydrate or lipid compounds, such as sulfoglycans and sulfatides, bearing little quantitative impact.

The mean Met content of body mixed proteins is situated between 2 and $3 \%$. The body requirements for both SAAs (Met + Cys) are evaluated at $13 \mathrm{mg} \mathrm{Kg}^{-1}$ day $^{-1}$ [49]. The mean molar $\mathrm{N}: \mathrm{S}$ ratio in mammalian tissues exhibits a remarkable stability turning around 14.5: 1 in at least four different animal species (rat, dog, cattle, man) [48]. Under physiological circumstances, kinetic studies undertaken in healthy adults consuming well-balanced diets with appropriate Met intake levels indicate that both RM and TS pathways split into nearly equivalent fractions [50,51]. In the case of alterations in Met supply, the body exploits its enzymatic equipment to modify the respective proportions of Met fluxes into RM and TS pathways so as to maintain Met homeostasis [52]. The redistribution of Met between two competing pathways is notably coordinated by intracellular SAM concentration working as allosteric inhibitor of the Cterminal regulatory domain of C $\beta S$ [53]. C $\beta S$ is a modular homotetrameric protein (252 $\mathrm{kDa}$ as $\mathrm{MM}$ ) comprising also a central catalytic core involved in PLP-dependent reactions and a N-terminal domain containing an heme iron binding site working as redox sensor [54] .

$\mathrm{S}$ fulfills important roles in all living systems, determining the structure and activity of a number of molecules and governing a multitude of metabolic and catalytic processes. Peptide syntheses start with the binding of free Met molecules initiating tRNA to yield formyl-methionyl-RNA launching the process of mRNA translation [55]. Cys sulfhydryl groups are implicated in the conformation of $\mathrm{Zn}$ finger motifs involved in protein-DNA recognition and replication [56]. The formation of intra- or intercatenary S-S bridges occurring during the maturation of nascent proteins is grounded on the oxidation of Cys sulfhydryl groups defining their tertiary and quaternary conformations hence their physico-chemical stability [57]. Many biological proteins may undergo $\mathrm{O}$ - or $\mathrm{N}$ - sulfonate esterification processes, ubiquitous reactions which may activate or inactivate their physiological properties, affinities and turnover rates as shown for thyroid, adrenal, sexual hormones and for pituitary and gastro-intestinal peptides [58,59]. Finally, $\mathrm{S}$ is involved in the synthesis and activity of many molecules of prominent biological significance such as co-enzyme A, thiamine (vitamin $\mathrm{B}_{1}$ ), biotin, metallothioneins and insulinlike growth factor-binding proteins. It is of interest to note that the oxidation rate of Met remains low but nevertheless constant even when its intake is below requirements [45]. Maintenance of measurable rates of Met oxidation unrelated to dietary Met supply supports the view that the IAA fulfills minimal obligatory activities likely to be of survival importance. Indeed, the bioavailability of Met is vital for the preservation of both TBN and TBS pools. When SAAs are withdrawn from the customary diet of large mammalian species, the rate of $\mathrm{N}$ ( and presumably of $\mathrm{S}$ ) losses exceeds that caused by all other IAA-deficiencies, being almost as great as when a protein-free regimen is given $[60,61]$. The data suggest that Met may be rate-limiting for the mobilization of tissue proteins, playing major regulatory roles in the protein economy of body tissues, perhaps even setting the minimum requirements for all of the other IAAs [62] .

\section{THE SULFUR-DEFICIENCY CONCEPT: HISTORI- CAL BACKGROUND}

The present section collects the main steps having led to the S-deficiency concept. To our knowledge, the first demonstration that $\mathrm{N}$ and $\mathrm{S}$ metabolisms are tightly interwoven was provided more than a century ago by 2 US investigators who defined themselves as enjoying an "uniform and perfectly normal condition of nutrition" [63]. The authors experienced the metabolic fate of a balanced diet providing $15 \mathrm{~g}$ $\mathrm{N}$ and 2,600 Kcal/day. The standard regimen was maintained during a 7-day period during which all urinary and fecal outputs were carefully collected and submitted to analytic procedures, allowing to measure baseline $\mathrm{N}$ and $\mathrm{S}$ excretory values. On days 4 and 6 of the clinical study, $50 \mathrm{~g}$ butter was isoenergetically replaced by $183 \mathrm{~g}$ lean beef meat. The extra supply of single well-defined portions of animal flesh to the basal regimen did proportionally increase the postprandial excretion of $\mathrm{N}$ and $\mathrm{S}$ values. The authors concluded that the excretion of $\mathrm{S}$ "ran closely parallel to that of $\mathrm{N}$ both on the normal days and on those affected by the extra ingestion of protein" [63]. Working along the same lines are the kinetic investigations using diets enriched with ${ }^{13} \mathrm{C}$-Met showing that the obligatory Met losses correlate with those predicted from obligatory $\mathrm{N}$-losses [64]. Because there exists neither protein nor $\mathrm{S}$ storage sites in the human body - as opposed to carbohydrate and lipid components - the bulk of extra $\mathrm{N}$ meal provided to protein-replete individuals is readily broken down and lost in the urinary output concomitantly with S-compounds eaten in excess and remaining unmetabolized. The data strongly suggest that the fate of dietary $S$ is not distinguishable from that of $\mathrm{N}$, implying that the body capacity to enter into anabolic drive and to generate net tissue protein gain is the requisite determinant of $\mathrm{S}$ accretion rate.

The next step refers to those studies having investigated the behavior of $\mathrm{N}$ and $\mathrm{S}$ during catabolic alterations. An hospital investigation was conducted by Cuthbertson in 1931 [65] upon patients recovering from bone fractures who were maintained on a constant intake of food. Their urinary outputs were collected during the days following injury, allowing the measurement of $\mathrm{N}$ and $\mathrm{S}$ using microKjeldahl analysis and ponderal recovery of S-trioxyde, respectively. The Scottish worker was the first to pinpoint negative $\mathrm{N}$ and $\mathrm{S}$ balances proportionate to the severity of initial impact and reflecting the magnitude of tissue proteolysis. He stated that the maximal $\mathrm{N}$ and $\mathrm{S}$ losses were usually attained between the $3^{\text {rd }}$ and $6^{\text {th }}$ days following the onset of fracture. The mean $\mathrm{N}$ excretion measured in 8 hospitalized patients was 17.53 $\mathrm{g} /$ day whereas that of total $\mathrm{S}$ amounted to $1.18 \mathrm{~g} / \mathrm{day}$, indicating very close correspondence with the $\mathrm{N}: \mathrm{S}$ ratio typical of mammalian tissues. The author also predicted - 50 years before the discovery of cytokines - that the spillover of $\mathrm{N}$ catabolites and obligatory S-losses should result from the "direct poisoning of the tissue cells such as might be supposed to take place in febrile conditions and in tissue injury" [65]. Working along the same catabolic lines is the demonstration that vigorous physical training entails varying degrees of muscular degradation documented by significantly increased $\mathrm{N}$ and $\mathrm{S}$ urinary losses again remaining bound within 14.5 : 1 ratios [66]. Using animal models and tissue cultures, Finkelstein et al. did initiate pioneer studies aiming at evaluating the tissue content of enzymes involved in the Met-Hcy cycle and in the TS pathway as well as their intrin- 
sic properties $[52,53]$. Carrying out a series of stable nuclideenriched Met studies upon healthy adult volunteers [45,47,51] and diseased patients [67], Young et al. did contribute new insights into most Met metabolic aspects. They were able to accurately quantify the respective and varying importance of TM, RM and TS fluxes in health and disease, helping to build a comprehensive understanding of the adaptive mechanisms set up by normal and stressed adult subjects to maintain intra- and extracellular Met homeostasis.

The notion that PEM might participate in the occurrence of S-deficiency states was born in the Republic of Senegal, West Africa, in 1986 [68]. The first field investigation was performed upon adult PEM and goitrous inhabitants living on nutritional autarky with local plant products. The main objective was to compare the clinical usefulness of TTR with that of plasma IAAs usually regarded as valid indicators of nutritional status [68]. The results did reveal that TTR and 7 among 8 IAAs manifest progressive lowering in their plasma concentrations as protein nutritional status deteriorates with the sole exception of Met which remained unaltered. The survey also showed that the patients did unexpectedly manifest a gradual elevation of their plasma Hcy values constrasting with the downregulation of cystathionine (Cysta) concentrations situated just after the CBS converting step [68]. The data were reminiscent of homocystinuria, inborn disease of metabolism characterized by genetic refractoriness of the central C $\beta S$ catalytic core to PLP stimuli [69]. A comparable field study was replicated in the Republic of Chad whose results did allow to rule out PLP, folates and cobalamins as causal factors and to strenghten the likely responsibility of subclinical protein malnutrition [38]. These observations led us to consider that PEM could affect the maturation of the middle C $\beta S$ domain reacting as a $\mathrm{N}$-status sensitive step and resulting in an acquired PLP-like enzymatic defect $[38,68]$. This hypothesis is supported by rat studies showing that low $10 \%$ casein diets cause a significantly diminished hepatic transcription of CBS-mRNA [70], leading to impaired enzyme activity and favoring the upstream accumulation of Hcy in biological fluids [71]. Supranormal Hcy values constitute a precursor pool readily driven into RM processes using two synergistic properties : Met-synthase manifests the highest Michaelis constant affinity for Hcy $\left(\mathrm{K}_{\mathrm{m}}\right.$ in the low micromolar range) compared to $\mathrm{C} \beta \mathrm{S}\left(\mathrm{K}_{\mathrm{m}} 1-25\right.$ $\mathrm{mMol} / \mathrm{L}$ ) [72] and the hepatic abundance of Met-synthase is increased under Met-restricted conditions [73]. Both adaptive mechanisms therefore work in concert to promote overstimulation of RM processes at the expense of downregulated TS activities. Conversely, transgenic mice characterized by overexpressed $\mathrm{C} \beta \mathrm{S}$ status are effectively capable of lowering high plasma Hcy levels [74]. Taken together, these findings stress the point that $\mathrm{C} \beta \mathrm{S}$ works as a bidirectional lockgate pivotally involved in the distribution of Hcy between RM and TS pathways.

Four preliminary reports coming from 3 different countries have paved the way suggesting that LBM could operate as determinant of Hcy dimorphism in healthy adolescents, adult persons and elderly individuals [75-78]. The most elaborate clinical investigation, using single and multivariate regression analysis models, was recently published by Battezzatti et al. showing unambiguously that LBM is a major determinant positively correlated with Hcy plasma values [17]. We assume that the size of the metabolically active
LBM works as the main determining factor of Hcy as well as of TTR concentrations [10] at least from birth until the end of adulthood. It has been recently proposed that the actual LBM size could work as a direct sensor governing the level of C $\beta S$ activity [48]. The data imply that throughout the whole lifespan of healthy adults, the hepatic production of both TTR and Hcy stands under LBM status-dependency. These biomarkers nevertheless demonstrate divergent specificities in two clinical conditions, namely old age and protein malnutrition. First, as above-mentioned, TTR displays declining trends following the shape of LBM downsizing during the ageing process [10] whereas Hcy manifests rising tendencies [79] unrelated to vitamin B status [80]. It has been suggested that disconnection of Hcy from LBM control in elderly persons could result from centrallymediated rearranged hormonal and stimulatory impulses [10]. The data imply that older people constitute a vulnerable group at higher risk of cardiovascular mortality. In this population group, the measurement of Hcy is endowed with a predictive power going beyond that provided by classical Framingham criteria [81], making the routine use of TTR mandatory to disentangle the PEM component associated with the ageing process [82]. Second, PEM states are characterized by the suppression of liver TTR synthesis [83] and the downregulation of all protein components found in Table 1 whereas the upstream sequestration of Hcy progressively increases in opposite direction as an effect of C $\beta S$ inhibition [38,48]. Fig. (2) summarizes the negative correlation linking the deterioration of protein nutritional status and the adaptive HHcy response.

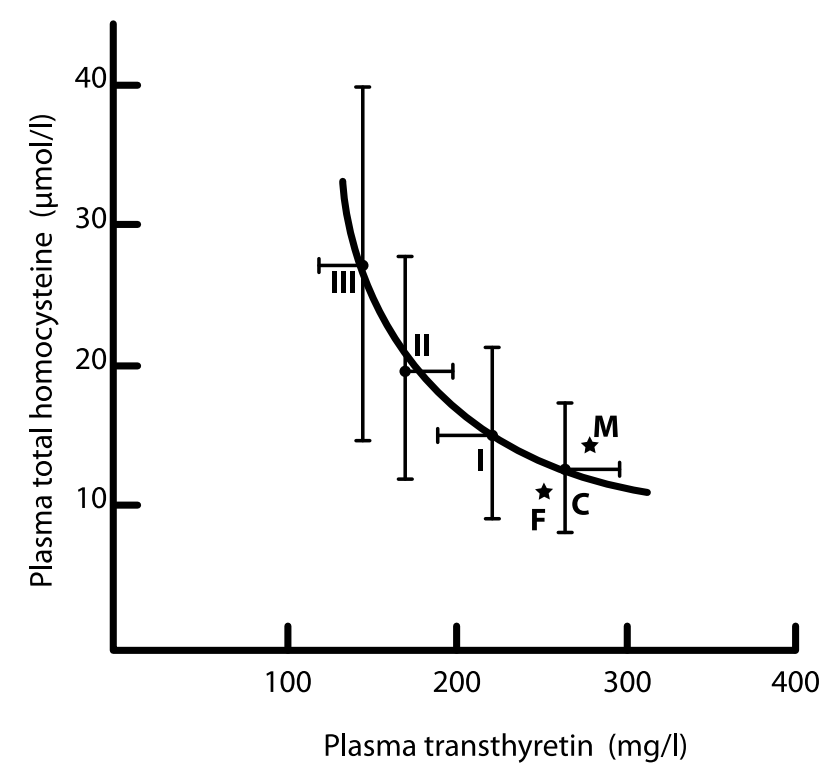

Fig. (2). Correlation linking TTR to Hcy in nutritional studies. TTR and Hcy concentrations were measured in control subjects (C) and in three cohorts of 20 subclinically malnourished and iodinedeprived adult individuals representing the stages I, II and III of goitrous swelling following WHO criteria. TTR and Hcy values are expressed as mean \pm standard deviation (horizontal and vertical bars). In the $\mathrm{C}$ group, male (M) and female (F) results are shown separately, indicating that both TTR and Hcy manifest gender dimorphism. The data reveal that declining nutritional status, as assessed by TTR values, is negatively correlated with rising Hcy concentrations. 


\section{HHCy RESULTING FROM UNACHIEVED N : S BODY REPLENISHMENT}

Met homeostasis appears as the net result of several salvage mechanisms maximizing intestinal absorption rates and minimizing fecal and kidney losses. Under steady state conditions, Met orally given undergoes rapid and efficient absorption rates [84] with negligible fecal losses that are poorly modified by significant alterations in $\mathrm{N}$ intake [85]. Methioninuria is barely detectable in healthy individuals, pointing to very high renal tubular recovery rates [86]. In the case of dietary Met overload, intrahepatic accumulation of SAM attenuates the activity of RM enzymes and stimulates that of C $\beta S$ [87] enhancing the degradation of Met along the TS cascade and leading to increased sulfaturia highly correlated with the level of SAA intake [88]. The contrary biochemical patterns are recorded in population groups having adopted, for religious or socio-cultural motivations, a plant-based dietary lifestyle. It is generally agreed that most vegetarian formulas are healthier than equivalent animal-based regimens because they contain less total lipids, saturated fats and cholesterol and more fibers $[89,90]$. As a result, most vegetarian subjects have lower body mass index values and reduced incidence of obesity and diabetes. In contrast, the provision of some essential nutriments ( $\mathrm{Ca}, \mathrm{Fe}, \mathrm{Zn}$, long-chain n-3 fatty acids, cobalamins) by plant products may turn to become critical $[89,90]$. Most plant products contain less $\mathrm{N}$, are usually deficient in lysine and Met [91] and characterized by a mean $\mathrm{N}: \mathrm{S}$ ratio not optimally fulfilling human tissue requirements [48]. The urinary output of vegetarians living in developing countries discloses significantly much lower $\mathrm{N}$ and $\mathrm{S}$ concentrations than those measured in subjects consuming western rich-diets [92]. At low $\mathrm{N}$ intake, the $\mathrm{S}$ balance may even turn negative [85], explaining why vegetarian subjects incur the risk of subclinical protein depletion and permanent S-deficiency substantiated by HHcy status [10]. Western population groups having adopted extravagant lifestyles such as long-term consumption of raw foods of plant origin also develop HHcy status [93], a condition still worsened by uncooked or unprocessed preparations shown to further depress their biological value [94]. Such inappropriate dietary lifestyles deserve to be confronted with previous recommendations stating that plant products cannot insure safe coverage of human needs in IAAs unless at least $30 \%$ of total protein is derived from animal sources [95].

Most clinical investigations with HHcy vegetarian subjects have concluded that vitamin $\mathrm{B}_{12}$-shortage was the main causal factor. As aforesaid, cobalamin-deficiency is indeed one of the commonest deficiencies affecting mankind worldwide [35] but its true impact on vegan subjects may be questioned in the light of multivariate regression analyses usually yielding no more than 25-30\% of Hcy variance. Moreover, and contrary to previous ascertainments, the low cholesterol and saturated fats, and the high fiber content of plant regimens do not protect vegans against the risk of cardiovascular diseases (CVD) which should no longer be regarded as solely affecting populations living in affluent westernized societies. According to WHO estimates, about 16.7 millions people died every year from CVD, accounting for $30 \%$ of all deaths worldwide with more than half of these deaths occurring in developing countries [96]. The problem of CVD reaches top morbidity and mortality levels in the South Asian subcontinent [97], prompting cardiolo- gists from 5 different countries (Bengladesh, India, Pakistan, Nepal, Sri Lanka) to exhort their governments focusing more attention on CVD disorders [98]. The classical CVD risk factors (dyslipidemia, high blood pressure, diabetes mellitus, tobacco smoking) mainly affect individuals living in urban areas and having adopted western dietary lifestyles. Emphasis put on cholesterol and lipid fractions has disregarded the protein component of most disease processes and LBM depletion as ensuing complication [10] The gap between epidemiology data and laboratory findings is illustrated by a recent investigation showing that a notable proportion of Indian patients remain HHcy-resistant to tri-vitamin-B therapy [99]. Poor rural dwellers consuming traditional vegetable dishes could well suffer generalized HHcy status best explained by overall subclinical PEM possibly coexisting with cobalamin and/or folate deficiencies. The concept is supported by studies showing that Asian immigrants living in western countries and keeping alive their previous dietary habits consume higher amounts of plant products than do Caucasian inhabitants. These expatriates may develop HHcy status despite normal plasma folate levels and only mild reduction of cobalamin values [100].

Diminished $\mathrm{N}$ and $\mathrm{S}$ tissue accretion rate is likely to occur in all forms of subclinical protein restriction [38] and in anorexia nervosa [39]. Medical [76] or surgical treatments of morbid obesity using gastroplasty procedures [101,102] may cause the expected FM and BW losses but are often associated with varying stages of protein malnutrition [103]. Malabsorptive syndromes are integral part of declared PEM, capable of causing within some months LBM downsizing and occurrence of secondary HHcy status. LBM was found the sole independent variable negatively correlated with rising Hcy values in patients submitted to weight-reducing programs [76]. Intestinal malabsorption may likely be incriminated as LBM-downsizing factor in both ulcerative colitis and Crohn's disease [104] although these last morbidities also comprise proinflammatory elements rendering more complex the identification of true HHcy causal factors. Inasmuch as protein-shortage is involved in morbid circumstances, serial TTR measurement would help to confirm LBM shrinkage and subsequent HHcy rise. TTR is a simple, rapid, inexpensive, noninvasive and reproducible micromethod whose nutritional usefulness has been described nearly 4 decades ago [105]. The scientific community has however expressed enduring reluctance for the TTR marker, explaining a number of misdiagnosed morbidities. Should the TTR biomarker be applied to the interpretation of current studies would have allowed their authors to confirm the TTR-Hcy relationship depicted in Fig. (2). Ongoing field surveys undertaken in Africa and still not published indicate that the combined measurement of TTR and Hcy display mirror images of each other. The most relevant aspects of the TTR-Hcy saga were recently described elsewhere [10].

\section{HHcy RESULTING FROM EXCESSIVE N : S BODY LOSSES}

Acute stressful disorders of any cause unleashes a shower of many cytokines fulfilling a myriad of autocrine, paracrine and endocrine functions [106]. A salient feature consists in enhanced tissue proteolyses in the whole body, allowing to stimulate the overproduction of defence and repair proteins by the liver and at the site of injury $[107,108]$. Several acute- 
phase reactants (APRs) constitute emblematic markers of the stress response amplitude [109]. The rate of protein degradation usually exceeds that undergoing neosynthesis $[110,111]$, leading to $\mathrm{N}$ balance becoming distinctly negative. The increased urinary leakage of $\mathrm{N}$-catabolites (mainly urea, but also creatinine, ammonia and other minor compounds) $[112,113]$ testifies that both metabolic and structural pools participate in the adaptive responses to acute stress in proportion to the magnitude of initial impact [11,114] . In very severe cases of injury in adult men, $\mathrm{N}$ urinary output may reach as high as $250 \mathrm{~g} \mathrm{~N}^{-1}$ week $^{-1}$ which corresponds to a loss of about $8 \mathrm{~kg} \mathrm{LBM} \mathrm{[11].} \mathrm{On} \mathrm{the} \mathrm{basis} \mathrm{of} \mathrm{Cuthbertson's}$ data [65], the corresponding $\mathrm{S}$ spillover may be evaluated at $17 \mathrm{mg} \mathrm{S}^{-1}$ week $^{-1}$, meaning more than $10 \%$ of TBS body stores. Another hallmark of acute stress is the reorchestration of endocrine status characterized by the overproduction of the so-called counterregulatory hormones (glucocorticoids, catecholamines, glucagon, somatotrophin) opposing the hypoglycemic and anabolizing properties of oversecreted insulin and contributing together with cytokines to the development of insulin refractoriness [107,108]. The molecular mechanisms whereby insulin resistance occurs are attributed to phosphorylation defects impairing tissue receptor and signaling systems $[115,116]$. Taken together, these adaptive hormonal alterations create a dichotomous stage identified by overall downregulation of synthetic processes in healthy tissues contrasting with upregulated activities in hepatic and inflamed territories [107,108]. The adequacy and efficacy of these multifaceted inflammatory events are depending on preexisting nutritional status of stressed patients, having led to the concept of a nutritionally dependent adaptive dichotomy (NDAD) [107,108]. As indicated previously, N and S losses reach top values some days after the initiation of acute injury [65], coinciding with the nadir recorded for $\mathrm{N}$ balance and TTR decline [11] and with culminating Hcy positions as shown in coronary heart infarct [117] and acute pancreatitis [118]. When the stressful condition subsides, provided that appropriate nutritional support is offered, $\mathrm{N}$ balance and TTR values gradually normalize [11] allowing Hcy to rejoin baseline levels within a couple of days [117,118]. In contrast, inadequate dietary management, metabolic or septic complications result in persistent $\mathrm{N}$ and $\mathrm{S}$ losses well recognized by subnormal TTR and supranormal Hcy concentrations.

Rapid elevation of Hcy values is a common finding correlated with disease severity and mortality in acutely ill patients [119]. Burn injury is characterized by a profound loss of body $\mathrm{N}$ [120] explaining why Hcy $\rightarrow$ Met conversion rate is severalfold increased above normal level [67]. The intensity of RM rates appears to be proportionate to the extent of tissue proteolysis and to the magnitude of TBN and TBS losses, favoring increased regeneration of S-compounds in the face of augmented S-demands. Contrary to the prevailing consensus, high Hcy values appear beneficial to the overall body economy in short-term studies, reflecting greater capacity to overcome $\mathrm{S}$-deficient states. The data are illustrated by HHcy pregnant women who experience efficient protection against the risk of intrauterine growth retardation [121]. Using Kaplan-Meyer statistical analysis, nephrologists were able to show that kidney patients with higher Hcy values benefit from better survival rates in comparison with low HHcy responders [122].
(Micro)albuminuria has low prevalence in a general healthy population [123] but appears as a frequent anomaly in chronic stressful disorders, mainly in diabetics and kidney patients. Diabetic patients losing around $4 \mathrm{gr}$ albuminuria $^{-1}$ day $^{-1}$ are foreseen to be depleted by $3.3 \mathrm{~kg} \mathrm{LBM} \mathrm{[124]} \mathrm{(a}$ loss of about $7 \%$ of metabolically active tissues) on a yearly basis. (Micro)albuminuria is usually associated with insulin resistance [125], reflecting the regulatory effects exerted by proinflammatory cytokines [126] and APRs [127] in the course of protracted disease. Insulin refractoriness nevertheless fulfills in both acute and chronic circumstances the same preventive role aiming at preserving LBM integrity. As expected, HHcy states are usually found positively correlated with disease activity and with the level of cytokines [126], APRs [127], albuminuria [128,129] and insulin resistance [130]. When available, serum and urinary urea and creatinine values also demonstrate positive correlations with Hcy levels, implying the participation of both metabolic and structural compartments. Mild or moderate elevation of all these stigmata reflects low grade inflammation and confirms that tissue proteolytic processes still persist unabated albeit operating with attenuated intensity.

Kidney patients are situated on the frontline of cardiovascular risks since they are reportedly capable of developing HHcy status in mild chronic renal insufficiency even in the absence of notable tissue damage [131]. The situation progressively aggravates in renal diseases of medium severity [132] and further deteriorates in end-stage renal failure characterized by exhaustion of metabolic capacities and strong refractoriness to vitamin therapy [40,133]. HHcy status frequently develop in type 1 [134], type 2 [135] and gestational diabetes mellitus [136] especially when patients display high blood levels of glycohemoglobin $\left(\mathrm{HbA}_{1} \mathrm{C}\right)$ evocative of poor glycemic control [135]. Patients suffering combined diabetes and nephropathy disclose elevated Hcy values, incuring the risk of significantly reduced life expectancy [129]. Cushing's disease entails changes in LBM likely caused by cortisol-induced protein catabolism and dissolution of bone collagen network [137]. Any surgical operation constitutes a stressful burden documented by negative $\mathrm{N}$ balance and depletion of LBM reserves whose AA residues are partly derived toward protein syntheses involved in mounting appropriate healing responses [11]. This is illustrated in elective cesarian section [138], in uninephrectomy [139] as well as in kidney [140], liver [141] and heart [142] transplantation procedures. Unusually high $\mathrm{N}$ - and S-urinary leakage is likely associated with the massive protein losses pathognomonic of eclampsia [143] and lipoid nephrosis [144]. Consistent with Wilson's observations [66], elite athletes submitted to strenuous muscular training disclose tissue degradation in proportion to the duration and intensity of physical activities [145,146]. Patients suffering AIDSdisease [147], lymphoblastic leukemia [148], cervical and breast cancer $[149,150]$ develop HHcy status whose magnitude seems proportionate to cell proliferation rate [149] and metastatic invasion [151] thereafter subsiding under successful therapy [151]. Subacute disorders characterized by cyclic bouts with spontaneous relapses or drug-induced remissions usually bear up and down alterations of Hcy values in relation to disease activity. Such erratic evolution is shown to occur in autoimmune processes [152], sickle cell disease [153] and parasitic infestations [154]. 


\section{CONCLUDING PERSPECTIVES}

The findings collected in the present review support the concept that, besides the classical vitamin causal factors, HHcy status may also develop as a result of LBM downsizing caused either by dietary $\mathrm{N}$ restriction / malabsorption or cytokine-induced tissue proteolysis. The reduction in LBM size implies that $\mathrm{N}$ balance turns negative, being associated in the former condition by restrained $\mathrm{S}$ tissue accretion rates and in the latter by concomitant $\mathrm{N}$ and S obligatory losses. The data illustrate the narrow metabolic interrelationships existing between $\mathrm{N}$ and $\mathrm{S}$ in mammalian tissues, stressing the role played by ${ }^{32} \mathrm{~S}$ identified for the first time as essentiel nutrient in human nutrition. $\mathrm{S}$ essentiality is sustained by the fact that its depletion from body reserves entails major clinical complications documented notably by thrombovascular abnormalities [30-32]. The strong correlation found between HHcy and cardiovascular morbidity and mortality has been recognized since 1969 [30] and repeatedly confirmed by other investigations carried out in developed countries $[31,32,41,81,155,156]$. This situation constitutes a public health problem of growing importance in western ageing societies as HHcy incidence discloses exponential rise with increasing age [157]. The amplitude of the problem is less well substantiated in developing countries although preliminary surveys mainly performed in Asian countries [37,97-99] may be regarded as alarm signals predicting the occurrence of similar harmful disorders which remain to be causally identified in the light of overall subclinical PEM affecting vegan and low income population groups. HHcy is also incriminated into a panoply of cognitive and neurodegenerative deficits [158], bone fracture [159] and fetal growth retardation [121] among others. The advent of the S-deficiency concept is expected to generate worldwide public health impact and makes a plea for assessing the protein component taking part in the development of HHcy states.

Despite the fact that nutritional and inflammatory factors deplete TBN and TBS stores through distinct and basically unrelated physiopathogenic mechanisms, they nevertheless share in common the capacity to impair C $\beta S$ activity, to promote the upstream accumulation of Hcy and to stimulate $\mathrm{Hcy} \rightarrow$ Met remethylating processes. LBM thus integrates, as does TTR $[10,82]$, both nutritional and inflammatory facets of any disease spectrum, inhibiting $\mathrm{C} \beta \mathrm{S}$ so as to provide univocal responses safeguarding Met homeostasis as a high metabolic priority. The level of C $\beta S$ inhibition and the intensity of RM processes appear causally related to enhanced metabolic requirements, hence directly depending on LBM downsizing, reaching top responses in severe tissue depletion but disclosing mild or moderate Hcy elevations in rampant disturbances. There exists continuing discussion wondering about the mechanistic significance of HHcy with respect to cardiovascular diseases [160-163]. On the basis of data collected in the present review, we tentatively assume the following sequence of events : In all conditions where $\mathrm{N}$ inadequacy is implicated, S-deficiency is the primary trigger of HHcy status. It is nevertheless necessary to make a clear distinction between $\mathrm{N}$ - and S-deficiencies resulting from insufficient intake or those generated by hypercatabolic reactions. The former condition is encountered in the sizeable proportion of population groups living in developing areas [36-38] as well as in subjects from western countries having adopted extravagant vegetable lifestyles $[93,100]$ whose in- take does not meet the recommended dietary allowances of $13 \mathrm{mg} \mathrm{SAAs} / \mathrm{kg}^{-1} / \mathrm{day}^{-1}$. Those individuals face the direct insult caused by permanent $\mathrm{N}$ - and S-restriction which does not permit achievement of body $\mathrm{N}$ equilibrium, leading to a stage of dystrophic LBM maturation. HHcy status of those chronically depleted individuals appears as the dark side of efforts provided by the S-depleted body to maintain acceptable anabolic activities. The latter condition appears as the indirect consequence of cytokine-induced acute and chronically evolutive illnesses characterized by concomitant losses of $\mathrm{N}$ - and S-substrates depleting both metabolic and structural compartments. The data collected in acute stressful disorders indicate that LBM downsizing, working alone, may cause Hcy elevation regardless of vitamin status $[117,118]$. In acute disorders, HHcy evolutionary patterns are too rapid to allow for the participation of vitamins whose plasma values usually remain unmodified $[117,118]$. It is of importance reminding that HHcy is beneficial in short-term events [121,122], allowing to readily supply the stressed body with S-derivatives under conditions of greater protein turnover. In long-run disorders, however, HHcy status becomes detrimental to the overall body vasculature [32,33], entailing subclinical endothelium dysfunction and diffuse blood vessel injury [164]. It seems likely that HHcy-induced vascular damage more particularly targets those vessels already deteriorated by preexisting lesions resulting from the natural unfolding of disease processes. Such synergistic vascular effects could explain the high prevalence of proteinuria, cerebral hemorrhage, cardiac infarct and deep vein thrombosis found in hypertensive, diabetic and kidney patients. This sequence of events is in accordance with the demonstration that, in chronically evolutive disorders, HHcy status precedes the development of (micro)albuminuria [128] which takes over from the loss of $\mathrm{N}$-catabolites recorded during the acute stage of disease $[107,108]$. Proteinuria reflects the slope of LBM depletion rate and constitutes the best marker of disease activity and mortality risk [128,129]. Insulin resistance remaining correlated with urinary protein leakage $[125,165]$ appears as the ultimate signal indicating that the stressed body still strives to curb LBM losses to the minimally required needs compatible with survival.

Our data support the view expressed by Italian workers suggesting that Hcy, due to its large implication in many morbidities, could well be "a marker of disease or of a metabolic derangement in which the leading actor is another parameter still unknown" [163]. We assume that this unrecognized parameter is S-deficiency, resulting either from unachieved LBM replenishment or from sickness-induced LBM narrowing. The lesson to learn from this review is that upholding an "appropriate LBM must remain the major outcome measure of protein-related health" [166]. Serial measurement of TTR obviously fulfills the task and constitutes the most reliable way to streamline dietary protein adequacy and / or to follow-up LBM distortions from normal in human morbidities.

\section{REFERENCES}

[1] Ault, W.C.; Kulp, J.L. Isotopic geochemistry of sulphur. Geochim. Cosmochim. Acta, 1959, 16, 201-235.

[2] Kelly, D.P. In: Sulphur in Biology; Elliot, K.; Whelan, J., Eds.; CIBA Foundation Symposium: Amsterdam Excerpta Medica, 1979, Vol. 72, pp. 3-18. 
[3] Mitchell, S.C. Biological Interactions of Sulfur Compounds. Taylor \& Francis: London, 1996.

[4] Huxtable, R.J. Biochemistry of Sulfur. Plenum Press: New York, 1986.

[5] Forbes, G.B. In: Present Knowledge in Nutrition; Ziegler E.E., Filer L.J., Eds.; $7^{\text {th }}$ ed.; ILSI Press : Washington DC, 1996, pp. 712.

[6] Komarnisky, L.A.; Basu, T.K. In Reviews in Food and Nutrition Toxicity; Preedy V.R., Watson R.R., Eds.; CRC Press : Boca Raton, 2005, Vol. 4, pp. 85-104.

[7] Bowman, B.A.; Russell, R.M. Present Knowledge in Nutrition, $8^{\text {th }}$ ed.; ILSI Press: Washington DC, 2001.

[8] International Commission on Radiation Protection. Report of the Task Force Group on Reference Man, Pergamon: Oxford, 1975, Vol. 23,

[9] Kotler, D.P.; Tierney, A.R.; Wang, J.; Pierson, R.N. Jr. Magnitude of body-cell-mass depletion and the timing of death from wasting in AIDS. Am. J. Clin. Nutr., 1989, 50, 444-447.

[10] Ingenbleek, Y. In: Recent Advances in Transthyretin Evolution, Structure and Biological Functions; Richardson S.J., Cody V., Eds.; Springer Verlag: Berlin, 2009, pp. 329-357.

[11] Ingenbleek, Y.; Young, V.R. Significance of transthyretin in protein metabolism. Clin. Chem. Lab. Med., 2002, 40, 1281-1291.

[12] Janssen, I.; Heymsfield, S.B.; Wang, Z.M.; Ross, R. Skeletal muscle mass and distribution in 468 men and women aged 18-88 yr. $J$. Appl. Physiol., 2000, 89, 81-88.

[13] Heymsfield, S.B.; Arteaga, C.; McManus, C.; Smith, J.; Moffitt, S. Measurement of muscle mass in humans : validity of the 24-hour urinary creatinine method. Am. J. Clin. Nutr., 1983, 37, 478-494.

[14] Heymsfield, S.B.; McManus, C.; Stevens, V.; Smith, J. Muscle mass : reliable indicator of protein-energy malnutrition severity and outcome. Am. J. Clin. Nutr., 1982, 35 (Suppl 5), 1192-1199.

[15] Cohn, S.H.; Gartenhaus, W.; Sawitsky, A.; Rai, K.; Zanzi, I.; Vaswani, A.; Ellis, K.J.; Yasumura, S.; Cortes, E.; Vartsky, D. Compartmental body composition of cancer patients by measurement of total body nitrogen, potassium and water. Metabolism, 1981, 30, 222-229.

[16] Ellis, K.J.; Yasumura, S.; Vartsky, D.; Vaswani, A.N.; Cohn, S.H. Total body nitrogen in health and disease: effects of age, weight, height, and sex. J. Lab. Clin. Med., 1982, 99, 917-926.

[17] Battezzatti, A.; Bertoli, S.; San Romerio, A.; Testolin, G. Body composition: an important determinant of homocysteine and methionine concentrations in healthy individuals. Nutr. Metab. Cardiovasc. Dis., 2007, 17, 525-534.

[18] Fors, H.; Gelander, L.; Bjarnason, R.; Albertsson-Wikland, K.; Bosaeus, I. Body composition, as assessed by electrical impedance spectroscopy and dual-energy X-ray absorptiometry, in a healthy paediatric population. Acta Paediatr., 2002, 91, 755-760.

[19] Kim, J.; Shen, W.; Gallagher, D.; Jones, A.; Wang, Z.M.; Wang, J.; Heshka, S.; Heymsfield, S.B. Total-body skeletal muscle mass : estimation by dual-energy X-ray absorptiometry in children and adolescents. Am. J. Clin. Nutr., 2006, 84, 1014-1020.

[20] Lohman, T.G.; Going, S.B. Body composition assessment for development of an international growth standard for preadolescent and adolescent children. Food Nutr. Bull., 2006, 27, S314-S325.

[21] Mauras, N. Growth hormone and sex steroids. Interactions in puberty. Endocrinol. Metab. Clin. North Am., 2001, 30, 529-544.

[22] Veldhuis, J.D.; Roemmich, J.N.; Richmond, E.J.; Rogol, A.D.; Lovejoy, F.C.; Sheffield-Moore, M.; Mauras, N.; Bowers, C.Y. Endocrine control of body composition in infancy, childhood, and puberty. Endocr. Rev., 2005, 26, 114-146.

[23] Cohn, S.H.; Vartsky, D.; Yasumura, S.; Vaswani, A.N.; Ellis, K.J. Indexes of body cell mass: nitrogen versus potassium. Am. J. Physiol., 1983, 244, E305-E310.

[24] Gallagher, D.; Visser, M.; De Meersman, R.E.; Sepulveda, D.; Baumgartner, R.N.; Wang, J.; Pierson, R.N.; Pi-Sunyer, F.X.; Heymsfield, S.B. Appendicular skeletal muscle mass: effects of age, gender, and ethnicity. J. Appl. Physiol., 1997, 83, 229-239.

[25] Hansen, R.D.; Raja, C.; Aslani, A.; Smith, R.C.; Allen, B.J. Determination of skeletal muscle mass and fat-free mass by nuclear and dual-energy X-ray absorptiometry methods in men and women aged 51-84. Am. J. Clin. Nutr., 1999, 70, 228-233.

[26] Cantoni, G.L. S-adenosylmethionine: a new intermediate formed enzymatically from L-methionine and adenosine triphosphate. $J$. Biol. Chem., 1953, 204, 403-416.
[27] Kang, S.S.; Wong, P.W.; Norusis, M. Homocysteinemia due to folate deficiency. Metabolism, 1987, 36, 458-462.

[28] Stabler, S.P.; Allen, R.H.; Savage, D.G.; Lindenbaum, J. Clinical spectrum and diagnosis of cobalamin deficiency. Blood, 1990, 76, 871-881.

[29] Ubbink, J.B.; van der Merwe, A.; Delport, R.; Allen, R.H.; Stabler, S.P.; Riezler, R.; Vermaak, W.J. The effect of subnormal vitamin B-6 status on homocysteine metabolism. J. Clin. Invest., 1996, 98, 177-184.

[30] McCully, K.S. Vascular pathology of homocysteinemia : implications for the pathogenesis of arteriosclerosis. Am. J. Pathol., 1969, 56, 111-128.

[31] Welsch, G.N.; Loscalzo, J. Homocysteine and atherothrombosis. $N$. Engl. J. Med., 1998, 338, 1042-1050.

[32] Lentz, SR. Mechanisms of homocysteine-induced atherothrombosis. J. Thromb. Haemost., 2005, 3, 1646-1654.

[33] Perla-Kaján, J.; Twardowski, T.; Jakubowski, H. Mechanisms of homocysteine toxicity in humans. Amino Acids, 2007, 32, 561-572.

[34] Selhub, J. Public health significance of elevated homocysteine. Food Nutr. Bull., 2008, 29(Suppl. 2), S116-S125.

[35] Stabler, S.P.; Allen, R.H. Vitamin B12 deficiency as a worldwide problem. Annu. Rev. Nutr., 2004, 24, 299-328.

[36] Hung, C.J.; Huang, P.C.; Lu, S.C.; Li, Y.H.; Huang, H.B.; Lin, B.F.; Chang, S.J.; Chou, H.F. Plasma homocysteine levels in Taiwanese vegetarians are higher than those of omnivores. J. Nutr., 2002, 132, 152-158.

[37] Yajnik, C.S.; Deshpande, S.S.; Lubree, H.G.; Naik, S.S.; Bhat, D.S.; Uraday, B.S.; Deshpande, J.H.; Rege, S.S.; Refsum, H.; Yudkin, J.S. Vitamin B12 deficiency and hyperhomocysteinemia in rural and urban Indians. J. Assoc. Physicians India, 2006, 54, 775782.

[38] Ingenbleek, Y.; Hardillier, E.; Jung, L. Subclinical protein malnutrition is a determinant of hyperhomocysteinemia. Nutrition, 2002, $18,40-46$.

[39] Moyano, D.; Vilaseca, M.A.; Artuch, R.; Valls, C.; Lambruschini, N. Plasma total-homocysteinemia in anorexia nervosa. Eur. J. Clin. Nutr., 1998, 52, 172-175.

[40] Van Guldener, C. Homocysteine and the kidney. Curr. Drug Metab., 2005, 6, 23-26.

[41] Joseph, J.; Handy, D.E.; Loscalzo, J. Quo vadis: whither homocysteine research ? Cardiovasc. Toxicol., 2009, 9, 53-63.

[42] Mueller, J.H. A new sulphur-containing amino acid isolated from the hydrolytic products of protein. J. Biol. Chem., 1923, 56, 157169.

[43] Womack, M.; Kemmerer, K.S.; Rose, W.C. The relation of dietary methionine and cysteine to growth. J. Biol. Chem., 1937, 121, 403410.

[44] Rose, W.C. The amino acid requirements of adult man. Nutr. Abstr. Rev. Ser. Hum. Exp., 1957, 27, 613-647.

[45] Raguso, C.A.; Ajami, A.M.; Gleason, R.; Young V.R. Effect of cystine intake on methionine kinetics and oxidation determined with oral tracers of methionine and cysteine in healthy adults. Am. J. Clin. Nutr., 1997, 66, 283-292.

[46] Gaull, G.; Sturman, J.A.; Raïhä, N.C. Development of mammalian sulfur metabolism : absence of cystathionase in human fetal tissues. Pediatr. Res., 1972, 6, 538-547.

[47] Fugakawa, N.K.; Ajami, A.M.; Young, V.R. Plasma methionine and cysteine kinetics in response to an intravenous glutathione infusion in adult humans. Am. J. Physiol., 1996, 270, E209-E214.

[48] Ingenbleek, Y. The nutritional relationship linking sulfur to nitrogen in living organisms. J. Nutr., 2006, 136, S1641-S1651.

[49] FAO/WHO/UNU. Energy and Protein Requirements. Report of a Joint FAO/WHO/UNU Expert Consultation Group. Technical Report Series $\mathrm{N}^{\circ} 724$, Geneva : WHO, 1985.

[50] Mudd, S.H.; Poole, J.R. Labile methyl balances for normal humans on various dietary regimens. Metabolism, 1975, 24, 172-175.

[51] Storck, K.J.; Wagner, D.A.; Burke, J.F.; Young, V.R. $\left[1-{ }^{13} \mathrm{C}\right.$; methyl- ${ }^{2} \mathrm{H}_{3}$ ] methionine kinetics in humans : methionine conservation and cystine sparing. Am. J. Physiol., 1990, 258, E790-E798.

[52] Finkelstein, J.D.; Martin, J.J. Methionine metabolism in mammals. distribution of homocysteine between competing pathways. J. Biol. Chem., 1984, 259, 9508-9513.

[53] Finkelstein, J.D.; Kyle, W.; Martin, J.J.; Pick, A.M. Activation of cystathionine synthase by adenosylmethionine and adenosylethionine. Biochem. Biophys. Res. Comm., 1975, 66, 81-87. 
[54] Jhee, K.H.; Kruger, W.D. The role of cystathionine $\beta$-synthase in homocysteine metabolism. Antioxid. Redox. Signal., 2005, 7, 813822.

[55] Flaim, K.E.; Liao, W.S.; Peavy, D.E.; Taylor, J.M.; Jefferson, L.S. The role of amino acids in the regulation of protein synthesis in perfused rat liver. II. Effects of amino acid deficiency on peptide chain initiation, polysomal aggregation, and distribution of albumin mRNA. J. Biol. Chem., 1982, 257, 2939-2946.

[56] Pabo, C.O.; Peisach, E.; Grant, R.A. Design and selection of novel $\mathrm{Cys}_{2} \mathrm{His}_{2}$ zinc finger proteins. Annu. Rev. Biochem., 2001, 70, 313340 .

[57] Betz, S.F. Disulfide bonds and the stability of globular proteins. Prot. Sci., 1993, 2, 1551-1558.

[58] Strott, C.A. Sulfonation and molecular action. Endocr. Rev., 2002, 23, 703-732.

[59] Ingenbleek, Y.; Young, V.R. The essentiality of sulfur is closely related to nitrogen metabolism: a clue to hyperhomocysteinemia. Nutr. Res. Rev., 2004, 17, 135-151.

[60] Owens, F.N.; Bergen, W.G. Nitrogen metabolism in ruminant animals : historical perspective, current understanding and future implications. J. Anim. Sci., 1983, 57(Suppl 2), 498-518.

[61] Fuller, M.F.; McWilliam, R.; Wang, T.C.; Giles, L.R. The optimum dietary amino acid pattern for growing pigs. 2. Requirements for maintenance and for tissue protein accretion. Br. J. Nutr., 1989, 62, 255-267.

[62] Millward, D.J.; Price, G.M.; Pacy, P.J.; Halliday, D. Maintenance protein requirements : the need for conceptual re-evaluation. Proc. Nutr. Soc., 1990, 49, 473-487.

[63] Sherman, H.C.; Hawk, P.B. On the elimination of nitrogen, sulphates, and phosphates after the ingestion of proteid food. Am. J. Physiol., 1900, 4, 25-49.

[64] Raguso, C.A.; Pereira, P.; Young, V.R. A tracer investigation of obligatory oxidative amino acid losses in healthy, young adults. Am. J. Clin. Nutr., 1999, 70, 474-483.

[65] Cuthbertson, D.P. The distribution of nitrogen and sulphur in the urine during conditions of increased catabolism. Biochem. J., 1931, 25, 236-244.

[66] Wilson, H.E.C. The effect of prolonged hard muscular work on sulphur and nitrogen metabolism. J. Physiol. (London), 1934, 82, 184-188.

[67] Yu, Y.; Burke, J.F.; Young, V.R. A kinetic study of L- ${ }^{2} \mathrm{H}_{3}$-methyl$1-{ }^{13} \mathrm{C}$-methionine in patients with severe burn injury. J. Trauma, 1993, 35, 1-7.

[68] Ingenbleek, Y.; Barclay, D.; Dirren, H. Nutritional significance of alterations in serum amino acid patterns in goitrous patients. Am. $J$. Clin. Nutr., 1986, 43, 310-319.

[69] Mudd, S.H.; Finkelstein, J.D.; Irreverre, F.; Laster, L. Homocystinuria : an enzymatic defect. Science, 1964, 143, 1443-1445.

[70] Yamamoto, N.; Tanaka, T.; Noguchi, T. The effect of a highprotein diet on cystathionine- $\beta$-synthase activity and its transcript levels in rat liver. J. Nutr. Sci. Vitaminol., 1996, 42, 589-593.

[71] Okawa, H.; Morita, T.; Sugiyama, K. Increased plasma homocysteine concentration in rats from a low casein diet. Biosci. Biotechnol. Biochem., 2006, 70, 3050-3053.

[72] Finkelstein, J.D. The metabolism of homocysteine: pathways and regulation. Eur. J. Pediatr., 1998, 157(Suppl 2), S40-S44.

[73] Finkelstein, J.D.; Kyle, W.E.; Harris, B.J. Methionine metabolism in mammals : regulation of homocysteine methyltransferases in rat tissues. Arch. Biochem. Biophys., 1971, 146, 84-92.

[74] Wang, L.; Jhee, K.H.; Hua, X.; DiBello, P.M.; Jacobsen, D.W.; Kruger, W.D. Modulation of cystathionine $\beta$-synthase level regulates total serum homocysteine in mice. Circ. Res., 2004, 94, 13181324.

[75] Dierkes, J.; Jeckel, A.; Ambrosch, A.; Westphal, S.; Luley, C.; Boeing, H. Factors explaining the difference in total homocysteine between men and women in the European Investigation into Cancer and Nutrition Potsdam study. Metabolism, 2001, 50, 640-645.

[76] Gallistl, S.; Sudi, K.M.; Erwa, W.; Aigner, R.; Borkenstein, M. Determinants of homocysteine during weight reduction in obese children and adolescents. Metabolism, 2001, 50, 1220-1223.

[77] Rauh, M.; Verwied, S.; Knerr, I.; Dörr, H.G.; Sönnichsen, A.; Koletzko, B. Homocysteine concentrations in a German cohort of 500 individuals: reference ranges and determinants of plasma levels in healthy children and their parents. Amino Acids, 2001, 20, 409418.
[78] Zamboni, M.; Di Francesco, V.; Zoico, E.; Bissoli, L.; Zivelonghi, A.; Mandragona, R.; Mazzali, G.; Tosoni, P.; Brocco, G.; Faccini, G.; Bosello, O. Homocysteine and life-style in the elderly. Aging (Milano), 2001, 13, 437-442.

[79] Rosenberg, I.H.; Selhub, J.; Jacques, P.F.; Bowman, B.A.; Gunter, E.W.; Johnson, C.L.; Murphy, R.S. In International Conference on Homocysteine Metabolism : From Basic Science to Clinical Medicine; Graham, I., Refsum, H., Rosenberg, I.H., Ueland, P.M., Eds.; Kluwer Academic: Norwell MA, 1997, pp. 183-187.

[80] Strassburg, A.; Krems, C.; Lührmann, P.M.; Hartmann, B.; Neuhäuser-Berthold, M. Effect of age on plasma homocysteine concentrations in young and elderly subjects considering serum vitamin concentrations and different lifestyle factors. Int. J. Vitamin. Nutr. Res., 2004, 74, 129-136.

[81] De Ruijter, W.; Westendorp, R.G.; Assendelft, W.J.; den Elzen, W.P.; de Craen, A.J.M.; le Cessie, S.; Gussekloo, J. Use of Framingham score and new biomarkers to predict cardiovascular mortality in older people: population based observational study. $\mathrm{Br}$. Med. J., 2009, 338, a3083.

[82] Ingenbleek, Y. Why should plasma transthyretin become a routine screening tool in elderly persons? J. Nutr. Health Aging, 2009, 13, 640-642.

[83] Strauss, D.S.; Marten, N.W.; Hayden, J.M.; Burke, E.J. Protein restriction decreases the abundance of serum albumin and transthyretin nuclear transcripts in rat liver. J. Nutr., 1994, 124, 1041-1051

[84] Horowitz, J.H.; Rypins, E.B.; Henderson, J.M.; Heymsfield, S.B.; Moffitt, S.D.; Bain, R.P.; Chawla, R.K.; Bleier, J.C.; Rudman, D. Evidence for impairment of transsulfuration pathway in cirrhosis. Gastroenterology, 1981, 81, 668-675.

[85] Prothro, J.; Mackellar, I.; Reyer, N.; Linz, M.; Chou, C. Utilization of nitrogen, energy, and sulfur by adolescent boys fed three levels of protein. J. Nutr., 1973, 103, 786-791.

[86] Stabler, S.P.; Marcell, P.D.; Podell, E.R.; Allen, R.H. Quantitation of total homocysteine, total cysteine, and methionine in normal serum and urine using capillary gas chromatography-mass spectrometry. Anal. Biochem., 1987, 162, 185-196.

[87] Finkelstein, J.D.; Martin, J.J. Methionine metabolism in mammals. Adaptation to methionine excess. J. Biol. Chem., 1986, 261, 15821587.

[88] Sabry, Z.I.; Shadarevian, S.B.; Cowan, J.W.; Campbell, J.A. Relationship of dietary intake of sulphur amino acids to urinary excretion of inorganic sulphate in man. Nature, 1965, 206, 931-933.

[89] Walter, P. Effects of vegetarian diets on aging and longevity. Nutr. Rev., 1997, 55, S61-S68.

[90] Key, T.J.; Appleby, P.N.; Rosell, M.S. Health effects of vegetarian and vegan diets. Proc. Nutr. Soc., 2006, 65, 35-41.

[91] Young, V.R.; Pellet, P.L. Plant proteins in relation to human protein and amino acid nutrition. Am. J. Clin. Nutr., 1994, 59, S1203S1212.

[92] Pathak, J.D.; Joshi, S.D. Nitrogen and sulphur elimination in 24 hours urine by elderly Indians. Indian J. Physiol. Pharmacol., 1981, 25, 41-47.

[93] Koebnick, C.; Garcia, A.L.; Dagnelie, P.C.; Strassner, C.; Lindemans, J.; Katz, N.; Leitzmann, C.; Hoffmann, I. Long-term consumption of a raw food diet is associated with favorable serum LDL cholesterol and triglycerides but also with elevated plasma homocysteine and low serum HDL cholesterol in humans. J. Nutr., $\mathbf{2 0 0 5}, 135,2372-2378$

[94] Friedman, M. Dietary impact of food processing. Annu. Rev. Nutr., 1992, 12, 119-137.

[95] Young, V.R.; Pellet, P.L. Current concepts concerning amino acids in adult and their implications for international planning. Food Nutr. Bull., 1990, 12, 289-300.

[96] World Health Organization. The World Health Report 2001. Health Systems: Improving Performance. WHO: Geneva, 2001.

[97] Lee, J.; Heng, D.; Chia, K.S.; Chew, S.K.; Tan, B.Y.; Hughes, K. Risk factors and incident coronary heart disease in Chinese, Malay and Asian Indian males: the Singapore Cardiovascular Cohort Study. Int. J. Epidemiol., 2001, 30, 983-988.

[98] Srivastava, R. South Asia's governments exhorted to focus on CVD. Lancet, 2002, 359, 858.

[99] Ghosh, K.; Khare, A.; Shetty, S. Fasting plasma homocysteine levels are increased in young patients with acute myocardial infarction from Western India. Indian Heart J., 2007, 59, 242-245. 
[100] Chandalia, M.; Abate, N.; Cabo-Chan, A.V. Jr.; Devaraj, S.; Jialal, I.; Grundy, S.M. Hyperhomocysteinemia in Asian Indians living in the United States. J. Clin. Endocrinol. Metab., 2003, 88, 10891095.

[101] Borzon-Chazot, F.; Harthe, C.; Teboul F.; Labrousse, F.; Gaume, C.; Guadagnino, L.; Claustrat, B.; Berthezène, F.; Moulin, P. Occurrence of hyperhomocysteinemia 1 year after gastroplasty for severe obesity. J. Clin. Endocrinol. Metab., 1999, 84, 541545.

[102] Sheu, W.H.; Wu, H.S.; Wang, C.W.; Wan, C.J.; Lee, W.J. Elevated plasma homocysteine concentrations six months after gastroplasty in morbidly obese subjects. Intern. Med., 2001, 40, 584-588.

[103] Faintuch, J.; Matsuda, M.; Cruz, M.E.; Silva, M.M.; Teivelis, M.P.; Garrido, A.B. Jr.; Gama-Rodrigues, J.J. Severe protein-calorie malnutrition after bariatric procedures. Obes. Surg., 2004, 14, 175181.

[104] Nakano, E.; Taylor, C.J.; Chada, L.; McGaw, J.; Powers, H.J. Hyperhomocysteinemia in children with inflammatory bowel disease. J. Pediatr. Gastroenterol. Nutr., 2003, 37, 586-590.

[105] Ingenbleek, Y.; De Visscher, M.; De Nayer, P. Measurement of prealbumin as index of protein-calorie malnutrition. Lancet, 1972, 2(7768), 106-109.

[106] Bienvenu, J.; Monneret, G.; Fabien, N.; Revillard J.P. The clinical usefulness of the measurement of cytokines. Clin. Chem. Lab. Med., 2000, 38, 267-285.

[107] Ingenbleek, Y.; Bernstein, L.H. The stressful condition as a nutritionally dependent adaptive dichotomy. Nutrition, 1999, 15, 305320.

[108] Ingenbleek, Y.; Bernstein, L.H. The nutritionally dependent adaptive dichotomy (NDAD) and stress hypermetabolism. J. Clin. Ligand Assay, 1999, 22, 259-267.

[109] Heinrich, P.C.; Castell, J.V.; Andus, T. Interleukin-6 and the acute phase response. Biochem. J., 1990, 265, 621-626.

[110] Tomkins, A.M.; Garlick, P.J.; Schofield, W.N.; Waterlow, J.C. The combined effects of infection and malnutrition on protein metabolism in children. Clin. Sci., 1983, 65, 313-324.

[111] Arnold, J.; Campbell, I.T.; Samuels, T.A.; Devlin, J.C.; Green, C.J.; Hipkin, L.J.; MacDonald, I.A.; Scrimgeour, C.M.; Smith, K.; Rennie, M.J. Increased whole body protein breakdown predominates over increased whole body synthesis in multiple organ failure. Clin. Sci., 1993, 84, 655-661.

[112] Beisel, W. Metabolic response to infection. Annu. Rev. Med., 1975, 26, 9-20.

[113] Long, C.L.; Birkhahn, R.H.; Geiger, J.W.; Blakemore, W.S. Contribution of skeletal muscle protein in elevated rates of whole body protein catabolism in trauma patients. Am. J. Clin. Nutr., 1981, 34, 1087-1093.

[114] Plank, L.D.; Connolly, A.B.; Hill, G.L. Sequential changes in the metabolic response in severely septic patients during the first 23 days after the onset of peritonitis. Ann. Surg., 1998, 228, 146158.

[115] Häring, H.; Kirsch, D.; Obermaier, B.; Ermel, B.; Machicao, F. Decreased tyrosine kinase activity of insulin receptor isolated from rat adipocytes rendered insulin-resistant by catecholamine treatment in vitro. Biochem. J., 1986, 234, 59-66.

[116] Hotamisligil, G.S.; Budavari, A.; Murray, D.; Spiegelman, B.M. Reduced tyrosine kinase activity of the insulin receptor in obesitydiabetes. Central role of tumor necrosis factor- $\alpha$. J. Clin. Invest., 1994, 94, 1543-1549.

[117] Turgan, N.; Boydak, B.; Habif, S.; Apakkan, S.; Özmen, D.; Mutaf, I.; Bayindir O. Plasma homocysteine levels in acute coronary syndromes. Jpn. Heart J., 1999, 40, 729-736.

[118] Yuzbasioglu, M.F.; Ozkaya, M.; Cakal, E.; Goksu, M. Changes in plasma levels of homocysteine in patients with acute pancreatitis. $J$. Pancreas, 2008, 9, 357-361.

[119] Schindler, K.; Zauner, C.; Buchmayer, H.; Födinger, M.; Wölfl, G.; Bieglmayer, C.; Heinz, G.; Wilfing, A.; Hörl, W.H.; SunderPlassmann, G. High prevalence of hyperhomocysteinemia in critically ill patients. Crit. Care Med., 2000, 28, 991-995.

[120] Wolfe, R.R.; Jahoor, F.; Hartl, W.H. Protein and amino acid metabolism after injury. Diabetes Metab. Rev., 1989, 5, 149-164.

[121] Infante-Rivard, C.; Rivard, G.E.; Gauthier, R.; Théorêt, Y. Unexpected relationship between plasma homocysteine and intrauterine growth restriction. Clin. Chem., 2003, 49, 1476-1482.

[122] Suliman, M.E.; Stenvinkel, P.; Qureshi, A.R.; Bárány, P.; Heimburger, O.; Anderstam, B.; Alvestrand, A.; Lindholm, B. Hyper- homocysteinemia in relation to plasma free amino acids, biomarkers of inflammation and mortality in patients with chronic kidney disease starting dialysis therapy. Am. J. Kidney Dis., 2004, 44, 455465.

[123] Metcalff, P.A.; Scragg, R.K. Epidemiology of microalbuminuria in the general population. J. Diabetes Complications, 1994, 8, 157163.

[124] Pupim, L.B.; Heimbürger, O.; Qureshi, A.R.; Ikizler, T.A.; Stenvinkel, P. Accelerated lean body mass loss in incident chronic dialysis patients with diabetes mellitus. Kidney Int., 2005, 68, 23682374.

[125] Mykkännen, L.; Zaccaro, D.J.; Wagenknecht, L.E.; Robbins, D.C.; Gabriel, M.; Haffner, S.M. Microalbuminuria is associated with insulin resistance in nondiabetic subjects: the insulin resistance atherosclerosis study. Diabetes, 1998, 47, 793-800.

[126] Tilg, H.; Moschen, A.R. Inflammatory mechanisms in the regulation of insulin resistance. Mol. Med., 2008, 14, 222-231.

[127] Festa, A.; D’Agostino, R. Jr.; Tracy, R.P.; Haffner, S.M. Elevated levels of acute-phase proteins and plasminogen activator inhibitor1 predict the development of type 2 diabetes : the insulin resistance atherosclerosis study. Diabetes, 2002, 51, 1131-1137.

[128] Jager, A.; Kostense, P.J.; Nijpels, G.; Dekker, J.; Heine, R.J.; Bouter, L.M.; Donker, A.J.M.; Stehouwer, C.D.A. Serum homocysteine levels are associated with the development of (micro)albuminuria: the Hoorn study. Arterioscler. Thromb. Vasc. Biol., 2001, 21, 74-81.

[129] Chico, A.; Pérez, A.; Córdoba, A.; Arcelús, R.; Carreras, G.; de Leiva, A.; González-Sastre, F.; Blanco-Vaca, F. Plasma homocysteine is related to albumin excretion rate in diabetic patients with diabetes mellitus: a new link between diabetic nephropathy and cardiovascular disease ? Diabetologia, 1998, 41, 684-693.

[130] Meigs, J.B.; Jacques, P.F.; Selhub, J.; Singer, D.E.; Nathan, D.M.; Rifai, N.; D'Agostino, R.B.; Wilson, P.W.F. Fasting plasma homocysteine levels in the insulin resistance syndrome: The Framingham offspring study. Diabetes Care, 2001, 24, 1403-1410.

[131] Robles, N.R.; Romero, J.; Gomez Casero, L.; Escola, J.M.; Ramos, J.L.; Sánchez Casado, E. Hyperhomocysteinemia in patients with mild chronic renal failure. Eur. J. Intern. Med., 2005, 16, 334-338.

[132] Perna, A.F.; Ingrosso, D.; Satta, E.; Lombardi, C.; Acanfora, F.; De Santo, N.G. Homocysteine metabolism in renal failure. Curr. Opin. Clin. Nutr. Metab. Care, 2004, 7, 53-57.

[133] Devriese, A.S.; Verbeke, F.; Schrijvers, B.F.; Lameire, N.H. Is folate a promising agent in the prevention and treatment of cardiovascular disease in patients with renal failure? Kidney Int., 2002, 61, 1199-1209.

[134] Saeed, B.O.; Nixon, S.J.; White, A.J.; Summerfield, G.P.; Skillen, A.W.; Weaver, J.U. Fasting homocysteine levels in adults with type 1 diabetes and retinopathy. Clin. Chim. Acta, 2004, 341, 27-32.

[135] Drzewoski, J.; Czupryniak, L.; Chwatko, G.; Bald, E. Hyperhomocysteinemia in poorly controlled type 2 diabetes patients. Diabetes Nutr. Metab., 2000, 13, 319-324.

[136] Guven, M.A.; Cetinkaya, A. Elevated plasma homocysteine levels in gestational diabetes mellitus. Acta Obstet. Gynecol. Scand., 2004, 83, 543-547.

[137] Terzolo, M.; Allasino, B.; Bosio, S.; Brusa, E.; Daffara, F.; Ventura, M.; Aroasio, E.; Sacchetto, G.; Reimondo, G.; Angeli, A.; Camaschella, C. Hyperhomocysteinemia in patients with Cushing's syndrome. J. Clin. Endocrinol. Metab., 2004, 89, 3745-3751.

[138] Zanardo, V.; Caroni, G.; Burlina, A. Higher homocysteine concentrations in women undergoing caesarean section under general anesthesia. Thromb. Res., 2003, 112, 33-36.

[139] Tsai, M.Y.; Aras, O.; Sozen, H.; Hanson, N.Q.; Woll, P.S.; Arends, V.L.; Hunnninghake, D.B.; Matas, A.J. Plasma homocysteine levels in living kidney donors before and after uninephrectomy. $J$. Lab. Clin. Med., 2004, 143, 340-343.

[140] Sobki, S.H.; Khan, S.A.; Al Mofawaz, T.A.; Saadeddin, S.M.; Al Suliman, M.; Al Khader, A. Homocysteine in renal transplant recipients : association with transplant duration and renal function. Ren. Fail., 2004, 26, 265-271.

[141] Herrero, J.I.; Quiroga, J.; Sangro, B.; Beloqui, O.; Pardo, F.; Cienfuegos, J.A.; Prieto, J. Hyperhomocysteinemia in liver transplant recipients: prevalence and multivariate analysis of predisposing factors. Liver Transpl., 2000, 6, 614-618.

[142] Parisi, F.; Kost-Byerly, S.; Saponara, I.; Di Donato, R.; Di Liso, G. Elevated plasma homocysteine concentrations after pediatric heart transplantations. Transpl. Int., 2000, 13(Suppl 1), S235-S239. 
[143] Ingec, M.; Borekci, B.; Kadanall, S. Elevated plasma homocysteine concentrations in severe preeclampsia and eclampsia. Tohoku J. Exp. Med., 2005, 206, 225-231.

[144] Arnadottir, M.; Hultberg, B.; Berg, A.L. Plasma total homocysteine concentration in nephrotic patients with idiopathic membranous nephropathy. Nephrol. Dial. Transplant., 2001, 16, 45-47.

[145] Hermann, M.; Schorr, H.; Obeid, R.; Scharhag, J.; Urhausen, A.; Kindermann, W.; Hermann, W. Homocysteine increases during endurance exercise. Clin. Chem. Lab. Med., 2003, 41, 1518-1524.

[146] Borrione, P.; Pigozzi, F.; Massazza, G.; Schonhuber, H.; Viberti, G.; Paccotti, P.; Angeli, A. Hyperhomocysteinemia in winter elite athletes: a longitudinal study. J. Endocrinol. Invest., 2007, 30, 367375 .

[147] Bernasconi, E.; Uhr, M.; Magenta, L.; Ranno, A.; Telenti, A. Swiss HIV Cohort Study. Homocysteinemia in HIV-infected patients treated with highly active antiretroviral therapy. AIDS, 2001, 15, 1081-1082.

[148] Ruud, E.; Holmstrom, H.; Brosstad, F.; Wesenberg, F. Children with acute lymphoblastic leukaemia have high plasma levels of total homocysteine at time of diagnosis. Scand. J. Clin. Lab. Invest., 2006, 66, 67-78

[149] Weinstein, S.J.; Ziegler, R.G.; Selhub, J.; Fears, T.R.; Strickler, H.D.; Brinton, L.A.; Hamman, R.F.; Levine, R.S.; Mallin, K.; Stolley P.D. Elevated serum homocysteine levels and increased risk of invasive cervical cancer in US women. Cancer Causes Control, 2001, 12, 317-324.

[150] Gatt, A.; Makris, A.; Cladd, H.; Burcombe, R.J.; Smith, J.M.; Cooper, P.; Thompson, D.; Makris, M. Hyperhomocysteinemia in women with advanced breast cancer. Int. J. Lab. Hematol., 2007, $29,421-425$

[151] Sun, C.F.; Haven, T.R.; Wu, T.L.; Tsao, K.C.; Wu, J.T. Serum total homocysteine increases with the rapid proliferation rate of tumor cells and decline upon cell death : a potential new tumor marker. Clin. Chim. Acta, 2002, 321, 55-62.

[152] Roubenoff, R.; Dellaripa, P.; Nadeau, M.R.; Abad, L.W.; Muldoon, B.A.; Selhub, J.; Rosenberg, I.H. Abnormal homocysteine metabolism in rheumatoid arthritis. Arthritis Rheum., 1997, 40, 718722 .

[153] Dhar, M.; Bellevue, R.; Brar, S.; Carmel, R. Mild hyperhomocysteinemia in adult patients with sickle cell disease: a common find- ing unrelated to folate and cobalamin status. Am. J. Hematol., 2004, 76, 114-120.

[154] Chillemi, R.; Zappacosta, B.; Simporè, J.; Persichilli, S.; Musumeci, M.; Musumeci, S. Hyperhomocysteinemia in acute Plasmodium falciparum malaria: an effect of host-parasite interaction. Clin. Chim. Acta, 2004, 348, 113-120.

[155] Boushey, C.J.; Beresford, S.A.; Omenn, G.S.; Motulsky, A.G. A quantitative assessment of plasma homocysteine as a risk factor for vascular disease: probable benefits of increasing folic acid intakes. JAMA, 1995, 274, 1049-1057.

[156] Wald, D.S.; Law, M.; Morris, J.K. Homocysteine and cardiovascular disease : evidence on causality from a meta-analysis. Brit. Med. J., 2002, 325, 1202-1206.

[157] McDermott, M.M. The international pandemic of chronic cardiovascular disease. JAMA, 2007, 297, 1253-1255.

[158] McCaddon, A.; Davies, G.; Hudson, P.; Tandy, S.; Cattell, H. Total serum homocysteine in senile dementia of Alzheimer type. Int. J. Geriatr. Psychiatry, 1998, 13, 235-239.

[159] McLean, R.R.; Jacques, P.F.; Selhub, J.; Tucker, K.L.; Samelson, E.J.; Broe, K.E.; Hannan, M.T.; Cupples, L.A.; Kiel, D.P. Homocysteine as a predictive factor for hip fracture in older persons. $N$. Engl. J. Med., 2004, 350, 2042-2049.

[160] Jacobsen, D.W. Determinants of hyperhomocysteinemia: a matter of nature and nurture. Am. J. Clin. Nutr., 1996, 64, 641-642.

[161] Christen, W.G.; Ajani, U.A.; Glynn, R.J.; Hennekens, C.H. Blood levels of homocysteine and increased risks of cardiovascular disease : causal or casual ? Arch. Intern. Med., 2000, 160, 422-434.

[162] Brattström, L.; Wilcken, D.E.L. Homocysteine and cardiovascular diseases: cause or effect? Am. J. Clin. Nutr., 2000, 72, 315-323.

[163] Marcucci, R.; Gori, A.M.; Abbate, R. Hyperhomocysteinemia : cause or effect of disease? Blood, 2005, 105, 3382-3383.

[164] Deckert, T.; Feldt-Rasmussen B.; Borch-Johnsen, K.; Jensen, T.; Kofoed-Enevoldsen, A. Albuminuria reflects widespread vascular damage: the steno hypothesis. Diabetologia, 1989, 32, 219-226.

[165] Fujita, H.; Narita, T.; Ito, S. Abnormality in urinary protein excretion in Japanese men with impaired glucose tolerance. Diabetes Care, 1999, 22, 823-826.

[166] Millward, D.J.; Jackson, A.A. Protein/energy ratios of current diets in developed and developing countries with a safe protein/energy ratio : implications for recommended protein and amino acid intakes. Public Health Nutr., 2003, 7, 387-405.

(C) Yves Ingenbleek; Licensee Bentham Open.

This is an open access article licensed under the terms of the Creative Commons Attribution Non-Commercial License (http://creativecommons.org/licenses/ by-nc/3.0/) which permits unrestricted, non-commercial use, distribution and reproduction in any medium, provided the work is properly cited. 